\title{
KAJIAN TENTANG GENDER PERSPEKTIF ISLAM \\ (Studi Analisis Tentang Posisi Perempuan dan Laki-laki dalam Islam)
}

\author{
Desi Asmaret \\ Fakultas Agama Islam Universitas Muhammadiyah Sumatera Barat \\ Jl. Pasir Kandang No. 4 Koto Tangah, Padang. \\ e-mail: desiasmaret.da@gmail.com
}

\begin{abstract}
The aim of this study is to find out the position of women and men in Islamic beliefs to encounter the challenges of feminists or feminism who have always questioned the differences in gender roles between women and men who have been considered lame and asismestris. Is this because of a false understanding of the structure of religious teachings normatively or not? The method used was library research with a qualitative approach. The data were collected from the Qur'an and Sunnah of the Prophet, books on gender and sociology and other relevant sources, then analyzing and drawing conclusions qualitatively. The results of the discussion found that differences between women and men were only privileges and groupings. Men and women are clearly different, but this difference is not intended so that each of them looks for their own ways, but to reach each other to achieve one goal, namely the continuity of life and human civilization itself. For this reason, it is recommended that Islamic law researchers reproduce research with a gender analysis perspective. So that the norms and substance of Islamic law are more easily understood and implemented.
\end{abstract}

Kata kunci: gender, feminis, laki-laki, dan perempuan

\section{PENDAHULUAN}

$G_{\text {klasifikasi gramatikal untuk benda- }}^{\text {ender, pada awalnya, adalah }}$ benda menurut jenis kelaminnya, terutama digunakan dalam bahasa-bahasa Eropa (AS. Hornby, n.d.). Arti gender kemudian berkembang untuk membedakan peran, prilaku, mentalitas dan karakteristik emosional antara lakilaki dan perempuan dalam masyarakat. Gender sebenarnya merujuk kepada peranan dan tanggungjawab antara lakilaki dan perempuan yang diciptakan oleh keluarga dan masyarakat (Herein Puspitawati, 2010: 2).

Perbedaan antara seks (jenis kelamin) dan gender adalah bahwa yang pertama berkaitan erat dengan ciri-ciri biologis dan fisik tertentu, sedangkan gender lebih banyak dibentuk oleh persepsi sosial budaya tentang steoretip perempuan dan laki-laki dalam sebuah masyarakat. Pembahasan sekitar gender selalu berangkat dari sebuah pertanyaan, apakah gender merupakan sebuah identitas yang natural ataukah sebagai produk dari sosialisasi kultural?

Para feminisme sepakat bahwa seks dan jenis kelamin dan perangkat reproduksi merupakan organ biologis yang bersifat natural. Dua jenis kelamin yang natural sering disebut dengan perempuan dan laki-laki. Sedangkan gender mengambil bentuk feminim dan maskulin sebagai bentuk identitas kedua. Dalam 
sosialisasi gender diyakini bahwa identitas gender yang feminin didefinisikan sebagai hal-hal yang berkaitan dengan sifat-sifat keperempuan seperti lemah gemulai, halus budi, berperasaan halus, mengalah dan pasif. Sedangkan maskulin didefinisikan sebagai hal-hal yang berkaitan dengan kejantanan yakni sifat-sifat yang identik dengan kelelakian (Zuli Agustin, 2018). Sedangkan Feminisme sering ditujukan kepada pembelaan terhadap hak-hak perempuan yang didasarkan kepada keyakinan akan kesamaan jenis kelamin. Dalam arti kata feminisme menunjuk kepada kesadaran setiap orang akan subordinasi perempuan dan berusaha untuk mengakhirinya dengan berbagai cara dan alasan (Dawam Mahfud, 2015).

Perbedaan gender (gender difference) yang selanjutnya melahirkan peran gender (gender role) sesungguhnya tidaklah menimbulkan masalah, sehingga tidak perlu digugat. Jadi kalau secara biologis (kodrat) kaum perempuan dengan organ reproduksinya seperti hamil, melahirkan, menyusui, kemudian mempunyai peran gender sebagai perawat, pengasuh dan pendidik anak, sesungguhnya tidak masalah dan tidak perlu digugat. Akan tetapi yang menjadi masalah adalah posisi ketidakadilan yang ditimbulkan oleh peran gender dan perbedaan gender itu. Yakni perbedaan yang bukan kodrati atau bukan ciptaan Tuhan, melainkan diciptakan oleh lakilaki dan perempuan melalui proses sosial budaya yang panjang. Oleh sebab itu, gender berubah dari waktu ke waktu, tempat ke tempat, bahkan dari kelas ke kelas. Sementara jenis kelamin biologis (seks) akan tetap dan tidak berubah.
Sejalan dengan makin terbukanya kesempatan belajar dan bekerja bagi perempuan, lambat laun kaum perempuan menyadari ketimpangan dan ketidakadilan perlakuan masyarakat terhadap dirinya. Muncul gerakangerakan emansipasi kaum perempuan sebagai reaksi terhadap perubahan sosial.

\section{METODE PENELITIAN}

Metode yang digunakan adalah library research (Penelitian Kepustakaan) dengan pendekatan kualitatif. Data-data dikumpulkan dari al-Qur'an dan Sunnah Nabi saw, buku-buku tentang tentang gender dan sosiologi serta sumbersumber lain yang relevan, kemudian melakukan analisis dan menarik kesimpulan secara deskriptif kualitatif.

\section{PEMBAHASAN}

\section{Pengertian Gender}

Kata gender sebenarnya merupakan kata serapan dari bahasa Inggris. Beberapa pengertian dari kata tersebut dapat penulis tulis sebagai berikut: Secara bahasa Gender berarti jenis kelamin, hal ini tercermin dalam definisi, "Gender is grammar in certain languages classification of noun or pronouns as masculine or feminine (AS. Hornby, n.d: 512). Gender berarti perbedaan yang tampak antara laki-laki dan perempuan dilihat dari segi nilai dan tingkah laku (The apparent disparity between man and women in values an behavior) (Victoria Neufield, 1984: 56).

Istilah gender dikenal sebagai kata pengganti jenis kelamin, namun terjadi perubahan makna yang dapat 
ditelusuri hingga dekade 1980-an sampai dengan 1993. Baru pada tahun 2011 gender digunakan untuk representasi diri seseorang sebagai lakilaki atau perempuan atau bagaimana is merespon terhadap institusi-institusi sosial yang didasarkan pada presentasi gender seseorang (Wikipedia, 2008).

Jadi menurut bahasa kata "gender" yang dibaca dan ditulis dalam Bahasa Indonesia dengan "gender" berarti jenis kelamin atau lebih tepat diartikan sebagai perbedaan laki-laki dan perempuan berdasarkan nilai dan tingkah laku karena kalau diartikan sebagai jenis kelamin berarti pengertian gender sama dengan seks. Seks adalah kodrat Tuhan yang secara permanen jelas berbeda antara laki-laki dan perempuan, sementara gender merupakan perbedaan yang bukan kodrat atau bukan ciptaan Tuhan, melainkan diciptakan oleh laki-laki dan perempuan melalui proses sosial dan budaya. Gender adalah sifat yang melekat pada laki-laki maupun perempuan yang dikonstruksi secara sosial dan budaya (Agus Sikwan, 2016).

Gender dapat dipahami suatu konsep yang digunakan untuk mengidentifikasikan perbedaan lakilaki dan perempuan dilihat dari segi pengaruh sosial budaya. Gender dalam arti ini adalah suatu bentuk rekayasa masyarakat (social constructions), bukan bersifat kodrati. Gender pada hakekatnya lebih menekankan aspek sosial, budaya, psikologis, dan aspek non biologis lainnya. Dengan kata lain gender lebih menekankan aspek maskulinitas atau feminitas seseorang dalam budaya tertentu. Dengan demikian, gender merupakan konstruksi yang dibentuk, disosialisasikan, diperkuat, bahkan diligitimasi secara sosial dan budaya. Pada gilirannya, perbedaan gender dianggap kodrati hingga melahirkan ketidakseimbangan perlakuan jenis kelamin (Sarifa Suhra, 2013: 377).

Ilmu sosiologi membedakan penggunaan istilah seks dengan istilah gender, Istilah seks menunjukkan identitas biologis seseorang perempuan dan laki-laki. Sedangkan istilah gender menunjukkan kepada keberadaan pokok seseorang atau posisi sosial kultural laki-laki dan perempuan (Agus Sikwan, 2016).

Laki-laki dan perempuan biasa dimaksudkan untuk membedakan sesuatu, adalah sebagaimana Eleanor Macoby yang dikutip oleh Michael S. Bassis (ahli sosiologi dari Antioch University) menjelaskan sebagai berikut:

"When we describe as masculine or feminine, was may mean that: 1 . They show those characteristics whics distinguish the sexes. 2. They examplify those characteristics we particulary value in the male and female sex role, or. 3.They display features which make them particulary attractive to the opposite sex. "(Ketika digambarkan seseorang sebagai maskulin (laki-laki) atau feminine (perempuan) maka yang dimaksud adalah:1.Laki-laki atau perempuan menggambarkan tentang karakteristik yang berbeda dengan seks. 2. Laki-laki atau perempuan menunjukkan karakteristik terutama tentang nilai dalam peranan seks (sex role) laki-laki dan perempuan.3.Laki-laki dan perempuan juga memamerkan tentang ciri-ciri (keistimewaan) yang dimiliki oleh laki-laki 
dan perempuan yang mampu menarik lawan jenisnya (lawan seksnya)" (Siti Ruhaini Dzuhayatin, 1996: 231).

Berdasarkan hasil diskusi Nasarudin Umar dkk, gender diartikan semata-mata merujuk pada karakteristik-karakteristik sosial, seperti perbedaan dalam gaya rambut, pola pakaian, jenis pekerjaan, dan aktifitas lain yang secara kultural dipelajari (Atika zuhrotus Sufiyana, 2017).

Atas dasar itu, dapat disimpulkan bahwa ilmu sosiologi menggunakan istilah gender sebagai perluasan dari istilah seks, di mana istilah gender mempengaruhi semua perbedaan yang berguna untuk menegaskan sifat-sifat kelelakian dan keperempuanan. Menurut penulis, ada beberapa unsur yang membangun pengertian gender yaitu:

1. Gender merupakan sifat yang melekat pada laki-laki dan perempuan atau suatu identitas sosial kultural pada laki-laki dan perempuan (Agus Sikwan, 2016).

2. Gender adalah sesuatu yang menandakan adanya perbedaan lakilaki dan perempuan dari segi psikologi, sosial dan kultural.

3. Gender adalah alat analisis dalam ilmu-ilmu sosial untuk mengidentifikasi perbedaan dan ketidakadilan struktural dan sistem.

Oleh sebab itu, penulis dapat merumuskan gender sebagai "suatu posisi yang diberikan oleh masyarakat terhadap laki-laki dan perempuan yang dipengaruhi oleh faktor sosial dan budaya."

\section{Gender dalam Islam}

\section{a. Perempuan dalam Masyarakat Zaman Jahiliyah}

Tradisi sebagian bangsa Arab sebelum Islam yang dikenal dalam sejarah dengan zaman Jahiliyah, telah menempatkan perempuan berada dalam kehinaan dan kenistaan. Sebagian lagi, berdasarkan temuan arkeologis tahun 6000 S.M (pra Islam), Catal Huyuk (sebuah pemukiman di kawasan Timur Tengah), justeru telah menempatkan posisi dominan dan tinggi terhadap perempuan yang dibuktikan dengan temuan pemakaman berisi perempuan dan berbagai lukisan sosok perempuan. Bahkan adanya budaya menghormati dewi ibu di sekitar daerah Mesopotamia dan Mesir (Leila Ahmad, 2000: 3).

Dominasi laki-laki dan kemerosotan status perempuan baru muncul setelah munculnya daya saing militer akibat masuknya bangsa asing. Sehingga saat itu muncullah masyarakat perkotaan pertama di Mesopotamia (di lembah sungai Tigris dan Efrat di bagian selatan Irak modern) antara tahun 3500 dan 3000 S.M (Leila Ahmad, 2000: 9).

Perlakuan rendah terhadap kaum perempuan itu rupanya didukung dan diakui pula oleh undang-undang masa itu di antaranya Undang-Undang Hamurabi dan Assiria. Di antara legalitas kekuasaan dan otoritas hanya menjadi milik suami dan ayah. Ayah berhak menggadaikan atau menjual istri dan anak 
perempuannya untuk membayar utang dan berhak menyerahkan anak perempuan mereka kepada dewa (Leila Ahmad, 2000: 10-11).

Meskipun di kalangan perempuan golongan atas (elit) dapat menikmati hak-hak mereka seperti, mengadakan perjanjian kekayaan dan memberikan kesaksian, namun kekuasaan mereka tetap berasal dari laki-laki yang menjadi tempat mereka bergantung. Khususnya perempuan di kelas bawah mengalami perlakuan brutal dan tidak terperikan dari kaum laki-laki. Bahkan masyarakat Sasania yang membentang di kawasan Irak. Irak setelah ditaklukkan oleh Islam pun masih mempunyai kebiasaan perkawinan incest. (seorang laki-laki dibolehkan mengawini saudara perempuannya, anak perempuannya, atau bahkan ibunya sendiri). Masih banyak lagi perlakuan yang tidak berperikemanusiaan yang dilakukan terhadap perempuan.

Tampaknya prilaku sebagian masyarakat Arab pra Islam yang telah memperlakukan kaum perempuan secara tidak bermoral tersebut, tergambar dalam beberapa ayat al-Qur'an, di antaranya: 1 . kebiasaan mewarisi perempuan (QS: al-Nisa': 19), kebiasaan mengawini istri anak laki-laki (menantu) dan menghimpun dalam perkawinan dua orang yang bersaudara (QS: alNisa: 22), kebiasaan menikahi perempuan tanpa membatasi jumlahnya (QS: al-Nisa: 3), kebiasaan mengubur bayi perempuan mereka hidup-hidup (QS: al-Nahl: 58-59).

\section{b. Penciptaan dan Status Perempuan dalam al-Qur'an}

Penciptaan dan status perempuan menurut al-Qur'an merupakan pangkal terjadinya perdebatan dalam memahami kedudukan perempuan yang setara dengan laki-laki. Semua dapat dipahami dengan memperhatikan bagai mana penjelasan al-Qur'an tentang proses penciptaan manusia pertama. Menurut Rifaat Hasan (sebagaimana dikutip oleh Yunahar Ilyas), "Jika laki-laki dan perempuan telah diciptakan setara oleh Allah swt. Maka dikemudian hari tidak bisa berubah menjadi a setara. Begitu juga sebaliknya, jika laki-laki dan perempuan telah diciptakan tidak setara oleh Allah swt., maka secara esensial dikemudian hari mereka tidak bisa menjadi setara (Yunahar Ilyas, 1997: 58).

Pandangan Rifaat Hasan di atas menunjukkan bahwa kaum feminis sesungguhnya merasa bagian penciptaan dan status perempuan dalam al-Qur'an merupakan bagian yang terpenting dalam memahami konsep kesetaraan laki-laki dan perempuan. Menurut al-Qur'an, Allah swt. Menciptakan manusia itu dari nafs (jiwa, energi, kehidupan, hakikat, dan esensi) yang tunggal dari manna atau sesuatu seperti alam. Allah swt. menciptakan pasanganpasangannya (Barbara Freyer Stowasser, 2001: 63). Banyak ayat al- 
Qur'an yang menceritakan tentang kejadian manusia itu dari nafs. Di antaranya firman Allah swt. dalam surat al-Nisa' ayat 1, al-Zumar ayat 6 , al-A'raf ayat 189 , dan al-Rum ayat 20-21.

Pada ayat-ayat tersebut tidak disebutkan secara eksplisit nama Adam dan Hawa, tetapi cukup diungkap dengan kata nafs wahidah dan zaujaha. Menurut penulis bukan masalah bagaimana perempuan dan laki-laki diciptakan seperti yang banyak diperselisihkan para ahli tafsir. Akan tetapi kenyataan yang harus diterima adalah bahwa perempuan adalah pasangan lakilaki. Penggunaan kata laki-laki dan perempuan dalam al-Qur'an surat al-Nisa': 1 merupakan manifestasi lahiriah dan realitas berpasangan yang hakiki ini dilipatgandakan dan berkembangbiak di muka bumi. Oleh sebab itu ayat ini sangat melampaui batas ruang dan waktu.

Al-Qur'an mengangkat status perempuan, yakni mengangkat mereka pada tinggkat kewibawaan spiritual yang sama dengan kaum pria. Berkaitan dengan ayat-ayat gender, penafsiran klasik yang menempatkan perempuan dalam posisi subordinat akan sulit diterima perempuan sekarang. Dengan demikian, penafsiran al-Qur'an harus mampu menampilkan Islam dalam semangatnya yang sejati dan bisa menjamin pertumbuhan dan perkembangan yang sejahtera pada umat manusia (Emawati, 2010).

\section{c. Persamaan antara Laki-laki dan Perempuan}

a. Persamaan Status

Meskipun terjadi perbedaan dalam memahami asal kejadian perempuan, dari tanah (seperti halnya Nabi Adam as.) atau dari tulang rusuk Adam a.s. namun tidak dapat dipungkiri lagi bahwa laki-laki dan perempuan samasama ciptaan Allah swt. yang tidak dibedakan di hadapan-Nya kecuali tingkat ketakwaannya.

b. Persamaan terhadap Penilaian amal Perbuatan

Kaum perempuan sejajar dengan kaum laki-laki dalam potensi intelektualnya. Mereka sebagaimana laki-laki dapat berfikir, mempelajari, kemudian mengamalkan apa yang mereka hayati dari berzikir kepada Allah swt. Seperti apa yang mereka pikirkan dari alam raya ini (Nasruddin Umar, 1999: xxxii). Hal ini sebagaimana firman Allah swt. dalam Al-Qur'an surat alHujurat ayat 13.

"Hai manusia, sesungguhnya Kami menciptakan kamu dari seorang lakilaki dan seorang perempuan dan menjadikan kamu berbangsa-bangsa dan bersuku-suku supaya kamu saling kenal mengenal. Sesungguhnya orang yang paling mulia di antara kamu di sisi Allah ialah orang yang paling bertakwa di antara kamu. Sesungguhnya Allah Maha Mengetahui lagi maha Mengenal."

Nilai yang paling membedakan dalam pandangan Allah swt. adalah takwa. Karena 
kata itu banyak mempunyai terjemahan definisi, maka di sini lebih dipilih dari Amina Wadud sebagai kesalehan (Amina Wadud, 2001: 81), yaitu sebuah istilah multidemensional berupa sikap perilaku yang menghindari apa yang dilarang sesuai dengan suatu sistem kodrat sosial dan kesadaran bahwa Allah swt. dengan menjalankan perilaku itu karena takzim kepada Allah swt.

Allah swt. tidak membedakan berdasarkan kekayaan, kebangsaan, jenis kelamin, melainkan berdasarkan takwa. Dari perspektif inilah semua perbedaan antara perempuan dengan perempuan antara laki-laki dengan laki-laki dan antara perempuan dan lakilaki adalah merupakan ciri khusus, yang membedakan, sehingga mempunyai cara untuk saling kenal mengenal.

c. Kesetaraan dan Keragaman Kodrat Perempuan dan Laki-laki

Manusia adalah makhluk yang bebas, otonom, dan bersaing. Semua mempunyai hak untuk mandiri sesuai dengan kemampuan mereka masingmasing. Inilah barangkali prinsip yang dipakai kaum feminis untuk mewujudkan kemandirian kaum perempuan. Akan tetapi kenyataan di alam modern ini, walaupun perempuan modern ingin mewujudkan kemandiriannya dan ingin mendapatkan hak otonom yang sejajar dengan laki-laki, namun mereka tetap mengidolakan lakilaki yang memberikan komitmen. Ini menunjukkan bahwa ada konflik batin dalam diri manusia modern baik laki-laki maupun perempuan. Jauh dilubuk hati laki-laki dan perempuan sebenarnya mereka masih merindukan adanya saling ketergantungan.

Perempuan perlu disayangi, dilindungi, dan laki-laki ingin diakui bahwa ia mampu memberikan perlindungan. Namun opsesiotonomi individu bebas dan mandiri kadangkala telah mengkorupsi naluri manusia yang sebetulnya banyak ketergantung an. Tarik menarik di antara dua kutub "ingin bebas" dan ingin ketergantungan dalam "diri individu" sering membawa konflik baik dengan dirinya maupun dengan orang di luar dirinya (Ratna Megawangi, 1999: 215).

Sesungguhnya di dalam diri manusia terdapat dualisme dalam dirinya. Kebebasan perempuan untuk dapat memajukan dirinya sebagai individu dan untuk memerankan secara optimal sisi lain identitas kodratnya yang tergantung pada lingkungan dan orang-orang yang dekat di sekitarnya. Demikian pula sebaliknya seorang laki-laki yang ingin mewujudkan kebebasan individualnya, adalah tidak lepas pula dari kebutuhan untuk melindungi orang-orang yang 
dicintainya. Keduanya ini merupakan sifat yang saling menyatu.

Kesatuan itu dapat dianalogikan dengan simbol yin/yang dalam falsafah Taoisme. Ungkapan kosmologi Cina, yang bisa diartikan sebagai sesuatu yang bersifat aktif dari yin dan yang reseptif atau kuat dan lemah serta laki-laki dan perempuan (Sachiko Murata, 1999: 31). Kehadiran simbol yin dan yang ini sudah dikenal dalam pemikiran Cina, ini menekankan konsep harmoni dan keseimbangan antara dua prinsip eksistensi (Sachiko Murata, 1999).

Kesatuan yin dan yang tidak lain adalah Tao, yaitu kualitas paling primodial, kualitas itu adalah kesatuan absolute. Kesatuan Tao ini memanifestasikan dirinya pada setiap ciptaan secara unik. Sehingga jadi differensiasi dengan kualitasnya masing-masing. Namun semua kualitas tidak selalu terkait dengan yin dan yang satu (Tao) (Sachiko Murata, 1999: 29).

Ratna Megawangi menafsirkan lebih lanjut falsafah dengan hubungan antara laki-laki dan perempuan sebagai berikut: Simbol yin dan yang juga menggambarkan kesatuan antara yin (kualitas yang feminine) dan yang (kualitas maskulin). Kesatuan tetap mempunyai ciri khasnya yaitu hitam (yang) putih (yin). Bagaimana lekukan ke dalam sisi hitam akan diisi oleh bagian sisi putih, dan lekukan ke dalam sisi putih akan diisi oleh sisi hitam, dan ini merupakan simbol kesatuan harmonis laki-laki dan perempuan dalam falsafah Taoisme. Laki-laki dan perempuan jelas berbeda, namun perbedaan ini tidak ditujukan agar masingmasing mencari jalannya masingmasing, tetapi untuk saling merengkuh mencapai satu tujuan, yaitu kelansungan kehidupan dan peradaban manusia itu sendiri. Selain itu simbol yin/yang tidak mutlak hitam dan putih, tetapi putih mempunyai titik hitam. Ini adalah simbol dan bahwa identitas bagian hitam tidak mutlak hitam begitu pula sebaliknya. Namun bagian hitam memang ada kualitas dominan yin dan kualitas dominan yang dalam segala sesuatu ciptaan, termasuk laki-laki dengan dominan maskulinnya dan perempuan dengan dominan femininnya. Di balik sifat dominan maskulin ini ternyata selaras dengan realitas, dimana setiap individu baik lakilaki maupun perempuan mempunyai dualisme sifat yang melekat pada dirinya, walaupun masing-masing mempunyai sifatsifat dominan karena pengaruh faktor kodratnya. Jika paradigma inklusif ini dapat diinternalisasikan oleh setiap laki-laki dan perempuan, maka kemerdekaan yang dimaksud adalah kemerdekaan yang menyalahi naluri kodrat masingmasing namun selalu menimbulkan keharmonisan yang 
tidak menimbulkan konflik atau merugikan orang lain dan lingkungannya (Sachiko Murata, 1999: 2018).

\section{PENUTUP}

\section{Kesimpulan}

Dari pembahasan tentang gender perspektif Islam dapat diambil kesimpulan bahwa perempuan dan lakilaki memang diciptakan Allah swt. berbeda, namun perbedaan ini adalah sunnatullah dan membuat keduanya serasi dalam mewujudkan kebersamaan hidup di dunia. Perbedaan tersebut adalah secara fisik (biologis), tabiat, tugas dan tanggungjawab, namun Allah swt juga menciptakan persamaan status dan penilaian terhadap amal perbuatan.

\section{Saran dan Rekomendasi}

Diharapkan para peneliti hukum Islam lebih memperbanyak penelitian hukum Islam dengan perspektif kajian gender. Agar norma dan substansi hukum Islam lebih mudah dipahami dan dilaksanakan di zaman modern ini.

\section{DAFTAR KEPUSTAKAAN}

Agustin, Zuli. 2018. Penerimaan Khalayak Perempuan terhadap identitas Maskulin pada Figur Model Iklan Kecantikan Olay Total Effect edisi Tara Basro. Universitas Airlangga.

Ahmad, Leila. 2000. Perempuan dan Gender dalam Islam, Akar-akar Historis Perdebatan Modern, Penerjemah, M.S., Nasrullah, Judul Asli, "Women and
Gender in Islam. Jakarta: PT. Lentera Basritama, cet. ke 1.

Dzuhayatin, Siti Ruhaini. 1996. Artikel Gender dalam Perspektif Islam, "Membincang Feminisme Diskursus Gender Perpsektif Islam. Surabaya: Risalah Gusti.

Emawati. 2010. Gender dan Islam. Studi Gender Dan Anak, 5(1).

Hornby, AS. n.d. Oxford Advanced Leoner's Dictionary (New Editio). London: Oxford University Press.

Ilyas, Yunahar. 1997. Feminisme dalam kajian Al-Qur'an, Klasik dan Kontemporer. Yokyakarta: Pustaka Pelajar, cet. I.

Mahfud, Dawam. 2015. Relevansi Pemikiran Feminisme Muslim dengan Feminisme Barat. Sawwa, 11(1).

Megawangi, Ratna. 1999. Membiarkan Berbeda, Sudut Pandang Baru Tentang Relasi Gender. Bandung: Mizan, cet. ke 1.

Murata, Sachiko. 1999. The Tao of Islam, Kitab Rujukan tentang Relasi Gender dalam Kosmologi dan Teologi Islam, Penerjemah: Rahmat Astuti dan MS. Nasharullah, The Tao of Islam, A Sourcebook on Gender Relationship ini Islamic Thought. Bandung: Mizan, cet. ke 7 .

Neufield, Victoria. 1984. Webster's New World Dictionary,. New york: Webster's New World Clevenland.

Puspitawati, Herein. 2010. Persepsi Peran Gender, Purwokerto. Studi Gender Dan Anak, 5(1). 
Sikwan, Agus. 2016. Sosiologi Gender.

Stowasser, Barbara Freyer. 2001. Reinterpretasi Gender, Wanita dalam AlQur'an, Hadis dan tafsir, Penterjemah, H.M. Mochtar Zoerni, Judul asli, "Women in Al-Qur'an, Tradition, and Interpretation. Bandung: Pustaka Hidayah, cet. ke 1 .

Sufiyana, Atika zuhrotus. 2017. Relasi Gender dalam kajian Islam. Tadrib, $3(1)$.

Suhra, Sarifa. 2013. Kesetaraan Gender dalam Perspektif al Quran dan Implikasinya Terhadap Hukum Islam. Al Ulum, 13(2).
Umar, Nasruddin. 1999. Argumen Kesetaraan Gender, Perspektif ALQuran. Jakarta: Paramadina, cet. ke 1.

Wadud, Amina. 2001. Qur'an Menurut Perempuan, Meluruskan Bias Gender dalam Tradisi Tafsir, Penterjemah, Abdullah Ali, Judul Asli: "Qur'an and Women, rereading The Secred Text From Woman's Perspective. Jakarta: PT. Serambi Ilmu Semesta, cet. ke 1.

Wikipedia. 2008. Gender Karakteristik Fisik dan psikologi yang membedakan maskulinitas dan feminitas. Retrieved from Wikepedia, http://id.m.wikipedia.org. 